\title{
Using Open Source Software for Undergraduate "Programming" Course
}

\author{
G. Zlobin \\ Ivan Franko National University of Lviv \\ Lviv, Ukraine \\ e-mail: zlobingg@gmail.com
}

\begin{abstract}
The report examines the use of FOSS in the "Programming" lecture course. Comparison of shells for structured programming in $C$ language is presented.
\end{abstract}

Index Terms - KUZJA IDE, development environment, C language

\section{INTRODUCTION}

In November 2012, the rector of Ivan Franko National University received a courtesy letter from Microsoft Ukraine with a proposal to make a plan for acquiring licenses for Microsoft products in 2012-2013. Since the budget of the Faculty of Electronics did not have the funds to purchase licenses for proprietary software, then, after tough discussions, it was decided to immediately transfer all training laboratories to FOSS. However, after the statement of the lecturer, who taught "Algorithmization and programming" and "Objectoriented programming" courses using exclusively proprietary software in Microsoft Windows operating system, Scientific Council of the Faculty has allocated 1000 USD to purchase a Dream Spark subscription for the faculty. But due to some mistakes in application forms the faculty did not receive this subscription. Subsequently, we managed to issue a free Dream Spark subscription for the Department of Radiophysics and CT. Due to this, in the three training laboratories of the Department of Radiophysics and CT licensed versions of Microsoft Windows 7 appeared, and in all other laboratories of the faculty OS Linux was installed. This led to the fact that students could not use the development tools that they used in the "Algorithmization and Programming" and "ObjectOriented Programming" course in the laboratories of Linux.

\section{MAIN}

In the 2017/18 academic year, a new specialty "Information Technologies" was opened at the faculty. For students of this specialty in the first semester the lecture course "Fundamentals of programming" is taught. To study introductory $\mathrm{C}$ language programming one should choose a simple shell, the work of which is very easy to master. Consider the following table.

The first two lines of the table mention Turbo $\mathrm{C}$ [1] and Borland $\mathrm{C} / \mathrm{C}++[2]$, which are well documented in the study literature, but they are designed to work only in MS DOS and
Windows. Let's focus on Kuzya [3], Geany [4] and Code::Blocks environments.

\begin{tabular}{|l|l|l|}
\hline $\begin{array}{l}\text { Shell for } \\
\text { programming }\end{array}$ & Operating Systems & $\begin{array}{l}\text { State of } \\
\text { development }\end{array}$ \\
\hline Turbo C & DOS & out of date \\
\hline Borland C/C++ & DOS, Windows & out of date \\
\hline Kuzya & $\begin{array}{l}\text { OS X, Windows, } \\
\text { Linux }\end{array}$ & develops \\
\hline Geany & $\begin{array}{l}\text { OS X, Windows, } \\
\text { Linux }\end{array}$ & develops \\
\hline Anjuta & Linux & develops \\
\hline Atom & $\begin{array}{l}\text { OS } X, \text { Windows, } \\
\text { Linux }\end{array}$ & develops \\
\hline Code::Blocks & $\begin{array}{l}\text { OS X, Windows, } \\
\text { Linux }\end{array}$ & develops \\
\hline Eclipse & $\begin{array}{l}\text { OS X, Windows, } \\
\text { Linux }\end{array}$ & develops \\
\hline Visual Studio Code & $\begin{array}{l}\text { OS X, Windows, } \\
\text { Linux }\end{array}$ & develops \\
\hline QtCreator & $\begin{array}{l}\text { OS X, Windows, } \\
\text { Linux }\end{array}$ & develops \\
\hline
\end{tabular}

Kuzya is the most simple shell for training. It was on simplicity that the main emphasis was made. For example, in this shell there is no project manager and, in general, no "project" concept. Work is done with one file that contains the text of the program. Immediately after launching KUZJA IDE, the student can start typing the application code without thinking of the shell's operation. Once saved, it can be compiled and run. For easy and fast coding, in the main menu there are templates of syntactic structures of $\mathrm{C} / \mathrm{C}++$ and Pascal languages. By pressing the left mouse button on the selected template, one can insert the corresponding text into the location where the cursor is located. Changing the language of the code automatically translates the templates. Highlights are also supported for the text of the program, which makes it easy 
to navigate within it. The minimum capabilities of this shell (only useful or necessary features left, for the purpose of training) allow one to concentrate as much as possible on the study of programming languages. Graphical engine was also created that allows to display graphic primitives using a Borland $\mathrm{C}++$ library. The language of dialogue is English, Ukrainian, Belarusian or Russian.

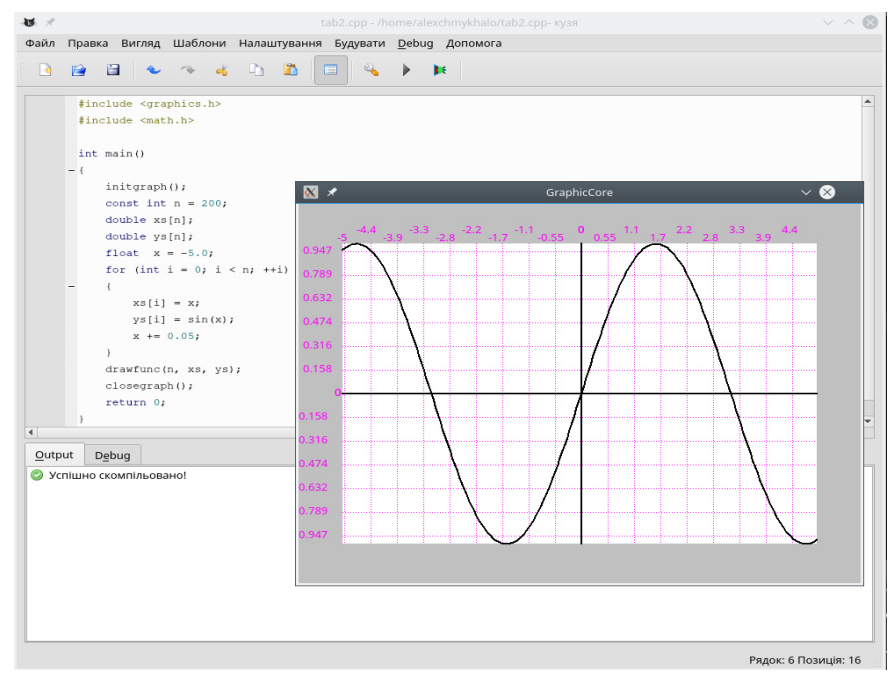

Fig. 1. Kuzya shell for programming

Geany is the software development environment written using the GTK + library. Available for the following operating systems: BSD, Linux, Mac OS X, Solaris, and Windows. Geany is distributed under the GNU General Public License. Geany does not have a compiler. To create executable code, the GNU Compiler Collection can be used or, if necessary, any other compiler.

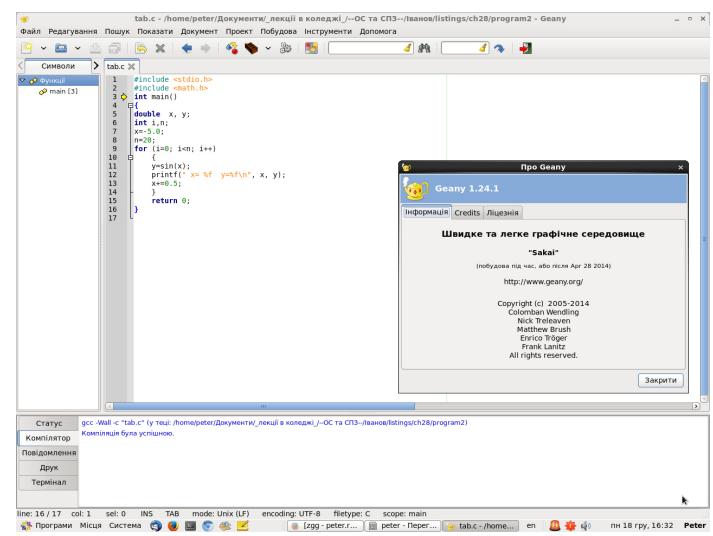

Fig. 2. Shell for programming Geany
Code::Blocks is a free cross-platform development environment. Code::Blocks is written in $\mathrm{C}++$ and uses the wxWidgets library. Having an open architecture it can be scalable due to modules. Supports C, C ++, D (with restrictions) and Fortran programming languages. Code::Blocks is developed for Windows, Linux and Mac OS

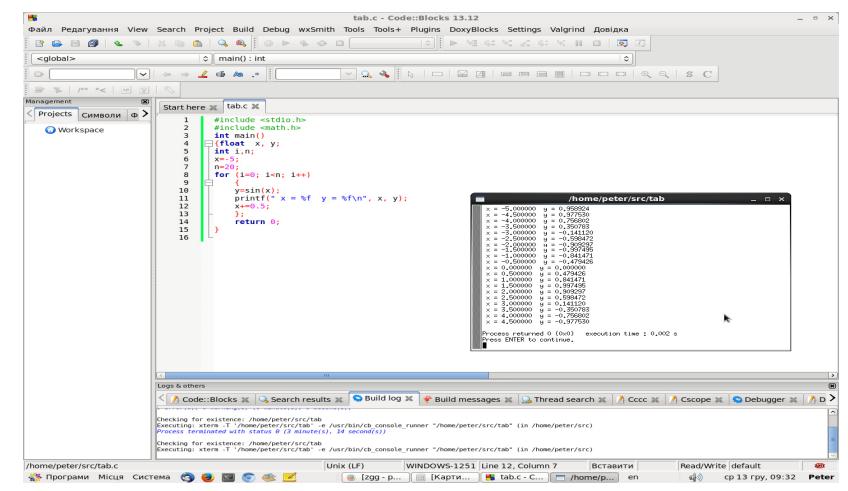

Fig. 3. Shell for programming Code::Blocks

\section{CONCLUSIONS}

1. All three shells are cross-platform, which allows students to work under the operating system installed at the workplace (stationary or portable computer). Due to this, students can get acquainted with cross-platform programming at the compilation level without sacrificing of additional time.

2. Kuzya and Geany shells allow the user to select the interface language (Russian, Ukrainian, English), which allows students to focus as much as possible on the work with the program being developed.

3. Kuzya shell has a graphical engine that allows students to build graphs of the studied functions. To construct graphs of functions that are stacked in Geany or Code::Blocks one will need to use external tools, such as gnuplot.

\section{REFERENCES}

[1] 1. Подбельский В.В., Фомин С.С. Программирование на языке Си: Учеб. пособие. - 2-е доп. изд. - М.: Финансы и статистика, 2001. 600 с.: ил.

[2] Шпак 3.Я. Програмування мовою С. - Львів: Оріяна-Нова. 2006. 432 с.: іл.

[3] https://sourceforge.net/projects/kuzya/files/kuzya-2.1.10/

[4] https://www.geany.org/

[5] www.codeblocks.org/ 